\section{Shaping up to Womanhood: Gender and Girls' Physical Education} Sheila Scraton

\author{
Open University Press: Buckingham \\ 1992 \\ ISBN $033509693 X £ 11.99 \mathrm{Pbk}$
}

\section{Research in Physical Education and Sport: Exploring Alternative Visions}

\author{
Edited by Andrew C. Sparkes \\ Falmer Press: London 1992 \\ ISBN $0750700750 £ 15.95 \mathrm{Pbk}$ \\ ISBN $0750700742 £ 40.00 \mathrm{Hbk}$
}

These books are a welcome contribution to the field of sport and physical education.

Sheila Scraton's work provides a much-needed insight into the relationship between physical education and gender, a topic often neglected both in research on gender and education and by feminism in general. The focus on physical education during adolescence raises many questions concerning the relationship between educational practice and ideologies of gender, femininity and sexuality.

Girls' physical education was slow to develop in the late nineteenth century. The emphasis was primarily on gentle exercise such as callisthenics. However, gradually a wider variety of sport was introduced, first in public schools and then in state schools. Physical education was shaped by ideologies of biological capacity, the need for women to develop the feminine qualities of grace and poise and the requirements of motherhood. Women were warned that vigorous exercise could be damaging and interfere with reproduction.

Many of these themes can still be identified today. Interviews with Physical Education teachers and advisers revealed a belief in natural differences between men and women. Boys were described as stronger and willing to 'launch themselves', while girls were seen to be more suited to gymnastics. Sports such as rugby and football were perceived to be particularly unsuitable for girls. Ideologies of the wife and mother role were not challenged and in practice had a significant impact on the ability/freedom of girls and female physical-education teachers to fully participate in sport.

In practice, physical education is more commonly taught as a singlesex subject in the early years of secondary schooling with mixed lessons introduced from the fourth year onwards. Mixed-sex teaching has the potential to challenge traditional views of sex differences by encouraging boys and girls to work together. In reality the situation is more complex. Girls wishing to play football in mixed groups may find it difficult to integrate into such groups due to a lack of previous training and negative ideas concerning their abilities. One of the main aims of physical education was to maintain standards of behaviour and appearance. This meant that girls and boys were often treated differently. Girls are encouraged to look good and behave like young ladies.

Ideologies of gender difference, femininity and sexuality are deeply ingrained in the policies, priorities and day-to-day practices of schools. They do not simply exist in the minds of individual teachers. Many schools attempt to encourage girls by providing activities which further emphasize femininity and looking good. Sheila suggests a more positive approach should include initiatives to ensure female-only space is available for girls to develop their confidence through collectivity. In addition girls should also be encouraged to take control of their own bodies.

Tackling inequality involves challenging existing ideologies, promoting an awareness of gender issues and encouraging change in physical education policy and 
practice. This book will go some way to doing just that.

The Sparkes book confidently tackles the current issues surrounding research in sport and physical education. Rather than being a research manual, the book explores the influence of theoretical traditions and the personal meanings that researchers bring to the research process. It is refreshing to find articles using a phenomenological approach, discourse analysis and life histories.

Sherry Woods uses phenomenological interviewing technique to explore the experiences of lesbian physical-education teachers. Participants were asked to reflect on their experiences and they commented on issues such as openness, the split between their professional lives as teachers and their personal lives as lesbians and strategies adopted to avoid disclosing their lesbian identities. This research is located within a critical framework which is concerned to challenge the homophobia and heterosexism within education. As such the article is vital in breaking the traditional silence regarding lesbian lives.

There are also articles on discourse analysis in education by Gill Clarke and on feminist research by Sheila Scraton and Anne Flintoff.

The book is well informed and accessible. Each chapter makes a distinctive contribution to this discussion of research paradigms and methods. As such it is essential reading for anyone interested in sport and physical-education research.

\section{Jackie Davis}

\section{Full Circles: Geographies of Women Over the Life Course}

\author{
Edited by Cindi Katz and Janice \\ Monk \\ London: Routledge 1993 \\ ISBN $0415075629 £ 12.99 \mathrm{Pbk}$ \\ ISBN $0415075521 £ 40.00 \mathrm{Hbk}$
}

\section{Different Places, Different Voices: Gender and Development in Africa, Asia and Latin America}

Edited by Janet Momsen and Vivian Kinnaird

London: Routledge 1993

ISBN $0415675637 £ 12.99$ Pbk

ISBN0 $415075386 £ 40.00 \mathrm{Hbk}$

Feminist geography: the combination of these two words too often still occasions surprised reactions, among feminists and among geographers, despite the growing body of exciting feminist work being done under the disciplinary auspices of geography. A great deal of this work is, undeservedly, little known beyond the disciplinary boundaries.
However, the establishment of a new series by Routledge under the general heading of International Studies of Women and Place, edited by Janice Monk and Janet Townsend, should begin to attract the wider attention that this body of scholarship deserves, not least for the eye-catching stylish covers to the first volumes.

The first two books in the series, Full Circles and Different Places, Different Voices, are both similar and different in their focus, emphasis and the range of contributors. Both are sets of collected essays that take as their central theme the commonalities and differences in the everyday experiences and coping strategies of women who are widely separated by geographical distance and by socio-economic circumstances - both their own and those of the nation-state in which they live. Each collection has a useful editorial introduction that situates the following chapters in the context of both specifically geographical scholarship and in feminist literature more broadly, thus ensuring that the curious reader from whatever place she 